\title{
Antifungal activity of brown, red and green alga seaweed extracts against Macrophomina phaseolina (Tassi) Goid., in pigeonpea var. CO (Rg) 7
}

\author{
S. AMBIKA* AND K. SUJATHA \\ Department of Seed Science and Technology, Agricultural College and Research Institute, MADURAI (T.N.) INDIA \\ (Email : ambikasingaram@gmail.com)
}

\begin{abstract}
In vitro studies was conducted to evaluate the effect of seaweed extracts of Caulerpa racemosa (green alga), Sargassum myricocystum (brown alga) and Gracilaria edulis (red alga) against the mycelial growth of Macrophomina phaseolina at different concentrations of 10,15,20,25 and 30 per cent along with control by poison food technique. The result revealed that extract of S. myricocystum showed significant antifungal activity against pathogen followed by G. edulis and C. racemosa. S. myricocystum (30\%) extract recorded the lowest mycelial growth (45.2, 50.6, 58.4 and $61.5 \mathrm{~mm}$ ) at 24, 48, 72 and $96 \mathrm{hrs}$ after incubation. Among the antagonists tested against Macrophomina phaseolina, the fungal antagonists Trichoderma viride was found to be most effective in reducing the mycelial growth than the bacterial antagonist Pseudomonas fluorescens. Both the antagonistic of fungi and bacteria has compatability with seaweed extracts in all the concentrations.
\end{abstract}

Key Words : Seaweeds, Soil borne pathogen, Red gram, Macrophomina phaseolina

View Point Article : Ambika, S. and Sujatha, K. (2015). Antifungal activity of brown, red and green alga seaweed extracts against Macrophomina phaseolina (Tassi) Goid., in pigeonpea var. CO (Rg) 7. Internat. J. agric. Sci., 11 (2) : 210-216.

Article History : Received : 01.01.2015; Revised : 01.05.2015; Accepted : 15.05.2015

\footnotetext{
* Author for correspondence
} 